In the afternoon of the same day there will be a garden party in the College Park, to which upwards of three thousand persons have been invited, and the day will close with the performance by the members of the University Choral Society of an ode written by G. F. SavageArmstrong, and set to music by Prof. Sir Robert Stewart, and by the civic ball.

On the Wednesday morning there will be a special Commencements for the conferring of honorary degrees. The Grace has already passed the Senate for eighty-three degrees, being a number equal to one-third of the total number of the expected guests and delegates. Among those on whom the degree of Doctor of Letters is to be conferred is Prof. Max Muller. The following will receive the degree of Master of Engineering: Lord Armstrong, Sir Benjamin Baker, Sir Isaac Lowthian Bell, Sir Charles William Wilson. The degree of Doctor of Sciences will be conferred on Prof. J. Burdon-Sanderson, Prof. Michael Foster, Prof. Ludimar Hermann, Sir George Murray Humphry, Prof. Julius Kollmann, Prot. Alexander Macalister, Prof. Richet, Prof. Sir William Turner, Wilhelm Valdeyer, Rev. Prof. Thomas George Bonney, Rev. William Henry Dallinger, Sir Archibald Geikie, Othniel Caleb Marsh, Baron Adolf Eric Nordenskiöld, Abbé Alphonse François Renard, John Hall Gladstone, George Downing Liveing, Lord Rayleigh, Prof. Joseph John Thomson, Prof. Thomas Edward Thorpe, Prof. William Augustus Tilden, Francesco Brioschi, Prof. Luigi Cremona, James Whitbread Lee Glaisher, Paul A. Gordan, Edward John Routh, George H. Darwin, Simon Newcomb, Isaac Roberts, F. Tisserand. The following are those who have been selected for the degree of Doctor of Medicine: H.R.H. I uke Charles of Bavaria, John Shaw Billings, Thomas Bryant, Sir Andrew Clark, Adolf Gusserow, Jonathan Hutchinson, Prof. Thomas Grainger Stewart. On the same day there will be a garden party at the Viceregal Lodge in Phanix Park, given by His Excellency the Lord-Lieutenant and Lady Zetland, and in the evening the College banquet will be held in the Leinster Hall. Five hundred, including all the guests and delegates, have been invited.

Thursday, July 7 , there will, in the morning, be a procession, from the Examination Hall of Trinity College to the Leinster Hall, of the College authorities and the delegates and others, to witness the presentation of addresses to the University by the delegates. A delegate from each country will make a short address, and the following have been invited to take their share in this interesting ceremony :-

Great Britain, her Colonies and Dependencies. - Sir James Paget, Bart., F.R.S.

America. - Prof. O. C. Marsh, of Yale University.

Austria-Hungary. - Prof. A. Vámbéry, of Buda-Pesth.

Belgium.-Prof. V. D'Hondt, of Ghent.

Denmark.-Prof. M. H. Saxtorph, of Copenhagen.

France.-Prof. Lannelongue, of Paris.

Germany.-Baron Ferdinand von Kichthofen, of Berlin.

Holland.-Prof. Tiele, of Leyden.

Italy. - Prof. Gaudenzi, of Bologna.

Nomway.-Prof. Hagerup, of Christiania.

K'ussia.--Prof. Wedenski, of St. Petersburg.

Switzerland. - Prof. Kollmann, of Basle.

Cambridsc:-Dr, Ieile, Vice.Chancellor.

Oxfort.--Rev. Dr. Boyd, Vice-Chancellor.

On the evening of this day there will be a dramatic performance by the students of the College, the piece selected being Brinsley Sheridan's comedy, "The Rivals." In the afternoon there will be a garden party at the Royal Hospital, Kilmainham, given by the Right Hon. the Commander of the Forces in Ireland and Lady Volseley.

The ceremonies will be brought to a close on Friday, No. I 183 , vOL. 46] on which day the following have been asked to address the College students: Profs. IV. Waldeyer, Berlin; F. Blass, Kiel ; $\Lambda$. Vámbéry, Buda-Pesth; F. Max Müller Oxford ; L. Cremona, Kome : B. J. Stockvis, Amsterdam; Léon Say, Paris; and Ceneral F. A. Walker, Massachusetts. The Athletic Union will hold their annual sports in the College Park and the University ball will be given in the afternoon and evening of this day.

On Saturday, July 9, the Royal Society of Antiquaries of Ireland have organized an excursion to Kells, the many objects of great antiquarian interest of which can easily be inspected within the limits of a short day from Dublin; the excursionists will leave the Great Northern Railway Station at 9 o'clock a.m., and return by the train reaching Dublin by 5.30 .

Every information can be obtained on writing to the Hon. Secretaries of the Tercentenary Committee, Trinity College, Dublin.

EXHIBITION AT NÜRNBERG BY THE GERMAN WATHE.HATICAL ASSOCIATION.

CHE following prospectus will show the scope and object of this Exhıbition :--

\section{Diutsche Mathematiker-Vercinigung.}

\section{München, Mai 1892.}

From September 12 to 18,1892 , the meetings of the "Deutsche Mathematiker-Vereinigung" and of the "Gesellschaft deutscher Naturforscher und Aerzte" will be held at Nürnberg.

At the proposition of the "Mathematiker-Vereinigung" the arrangement for an exhibition of models, drawings, apparatus, and instruments used in pure and applied mathematics is pro. posed. The project has secured the support of the Royal Bavarian Government.

The undertaking already enjoys the co-operation of a number of competent men of science, of several mathematical institutes of our colleges, besides that of various prominent publishers and well-known technical establisbments, and thus we may hope that the exhibition will answer the expectations of its founders, vis:

lo open to wider spheres the various auxiliaries used in the instruction and investigation of both pure and applied mathematics in the shape of models, apparalus, and instruments and to forward the interests of this kind of scientific work.

At the request of the committee of the MathematikerVereinigung 1 have the honour to invite you to participate in the exntbition, and to recommend to your special attention he following directions:-

I. Die mathematische Ausstellung gelegentlich der Versammlungen der "Deutschen Mathematiker-Vereinigung" und der "Gesellschaft deutscher Naturforscher und Aerzte" in Nürnberg will last from September 10 to 18,1892 . It com. prises mathematical models, drawings, apparatus, and instruments serving both for teaching and research in pure and applied mathematics.

II. The local committee of the Gesellschaft deutscher Naturforscher und Aerzte resp. the direction of the Bayerische Gewerbemuseum attends to the gratuitous granting of space required by the exhibitors.

III. The Deutsche Mathematiker-Vereinigung takes charge of all furniture, tables, scieens, \&c., attends to the opening and packing, also for supervision and case during the exhibition and

I In what belongs to the applicaticns, we include only those having principally a matheuatical interest. Concerning the experimental part of physics and those instruments, \&c., which are of more practical use, it should be mentioned that all those mure practical than theoretical relations will be displayed in a second exhibition, separate from ours, which compi i-es likewise the other branches of natural plilosophy and the medicine.

That exhibition, entitied "Fachtechnische Ausstellung," under the authority of the "Gesellschaft deutscher Naturfurscher und Aerzte" is arranged by the "Bayer,schen Geu erbemuseum in Nürnberg." under the direction of Mr. Th. von Kramer, whr has issued sperial programmes for that exhibition, and frum whom further infurmation may be obtained. 
for the insurance against fire. But assumes no responsibility either for damage or for loss of articles.

IV. Those who desire to exhibit under closed cases must do so at their own expense.

V. The charge of transport (to Nïrnberg) and, if desired, the insurance of transport is at the expense of the exhibitor. In what refers to the return transport, by the courtesy of the directors of the Bavarian and the other main lines of German railways free transport is guaranteed for all unsold objects of the exhibition. All expense of home-transport beyond this border is at the expense of the exhibitor.

VI. An explanatory detailed catalogue of the mathematical exhibition is to be issued.

The first part will consist of essays, having reference to problems, results, and methods of geometrical representation.

The second part of an enumeration of all articles exhibited in connection with detailed theoretical descriptions. Here, if desired, the prices may be added. This part of the catalogue will be fully illustrated to give a vivid impression of the exhibited articles. We respectfully request all institutes, publishers, \&c., to forward woodcuts, clichís, \&c., which may be inserted in the text.

An appendix to the catalogue will be published, including all advertisements which may hereafter serve as a directory for all those interested. ${ }^{1}$

VII. As far as possible all technical explanations of the articles will be undertaken by the committee.

VIII. The committee will attend to all sales and buyings (which are in view by various mathematical institutes of our Hochschulen) and give all desired information.

During the exhibition the sold articles must not be removed from the exhibition rooms, except with special permission of the committee.

IX. The intention to participate in the exhibition may be given by the use of the "Exhibition Announcement" until July r. Address : Herrn Prof. Dr. Walther Dyck, München, Hildegardstrasse $\mathrm{I} \frac{1}{2}$.

At the same time all papers and scientific notices for the catalogue respecting woodcuts and clichés for illustration must be sent to the same address."

The editors reserve the right of all abbreviation and change in the notes of Part 2 of the catalogue that the uniformity may require.

$\mathrm{X}$. All articles proposed for exhibition must be forwarded from September I to 7 , under the address : Mathematische Ausstelluug in Nürnberg (Bayern), zu Handen der Herren Danler and Co.

The return of all articles will be effected within two weeks after the close of the exhibition under the conditions fixed above (No. V.)

XI. For nearer information in respect to the intentions and the extent of the exhibition we annex a preliminary classification of the articles.

\section{Geometry. Theory of Functions.}

Models employed in elementary teaching of geometry (solid geometry, trigonometry, descriptive geometry).

Polyhedra. Division of surfaces and spaces in polygons respecting polyhedra.

Plane curves.

Curves in space. Developable surfaces.

Surfaces of the second order.

Higher algebraic surfaces.

Transcendental surfaces.

Models illustrating geometry of complexes.

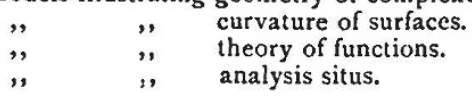

2. Arithmetic, Algebra, Integral Calculus.

Calculating machines. Slide rules.

Instruments for solving equations and for construction of functional relations.

The fees for insertion in the appendix are 30 Reichsmark for the whole page (great $\left.8^{\circ}\right), 18 \mathrm{~K} .-\mathrm{Ml}$. for $\frac{1}{2}$ page, $10 \mathrm{R}$.-M. for $\frac{1}{\$}$ page, $5 \mathrm{R} .-\mathrm{MI}$. for $\frac{1}{4}$ page.

${ }_{2}$ All advertisements for the Appendix and payments for same must not be deferred later than August $x$, to the same address, Prof. Dyck.

NO. I I 83 , VOL. 46]
Curvometers, planimeters, integrating machines, instluments for solving differential equations.

\section{Mechanics. Mathematical Physics.}

Models employed in elementary teaching.

Kinematics. Machines for description and transformation of curves and surfaces. l'antographs, perspectographs.

A pparatus for demonstration of mechanical principles.

Equilibrium and motion of a point.

Poinsot motion of a rigid body; precession, nutation; dynamical tops, gyroscopes.

Models and articles showing the effect of stress flexion and torsion of solids.

Flastic properties of solids (especially of crystals).

Hydrodynamics.

Geometrical representations and mechanical apparatus illustrating physical phenomena (for ex. vibrations, wave-motion, propagation of sound and lighr. Thermodynamic and electrodynamic phenomena).

XII. It is understood that the exhibitors declare their willingness to submit to the present rules and further dispositions ordered by the committee for the interest of the exhibition.

For all further information please address the undersigned delegate of the comwittee.

Prof. Dr. Walther Dyck, München, Hildegardestrasse $1 \frac{1}{2}$.

For the purpose of collecting and forwarding objects of interest, a Committee has been formed consisting of Lord Kelvin (Chairman), Lord Rayleigh, Profs. Sylvester, U. J. Lodge, G. F. Fitzgerald, W. G. Adams, Sir R. Ball, A. A. Common. Secretaries: A. G. Greenhill, O. Henrici.

The Secretaries will forward prospectuses and forms of application to intending exhibitors, and will take charge of objects at the Central Institution, Exhibition Road, South Kensington, S.W., and forward the objects at the proper time to Nürnberg, unless forwarded direct by the exhibitors.

\section{THE KEKULE FESTIVAL AT BONN}

N June I a remarkable demonstration took place at the University of Bonn. The occasion was the twenty-fifth anniversary of the call of August Kekule to the Professorship of Chemistry at that University. The details, which we have taken chiefly from the Kölnische Zeitung, will be of interest to the student of chemistry, and probably of value to the future historian of the science.

The ceremony began in the morning with an enthusiastic ovation on the part of the students. The chemical theatre was decorated with plarits; on the blackboard figured the benzene hexagon, made up with garlands of flowers, in the midst of which appeared the letters A. K. as a monogram of roses. At the usual lecture hour Prof. Kekule entered, and was greeted with great enthusiasm. One of the chemical students, Alfred Helle, delivered a graceful address, in which he congratulated his fellows on being privileged to sit at the feet of the greatest of living chemists, ending by calling for three cheers for the Professor, in which the audience heartily joined.

Prof. Kekulc then addressed the students, detailing with characteristic humour some passages in his life. He was, he said, a pupil at the Darmstadt Gymnasium, where he chiefly devoted himself to mathematics. He was destined by his father for the profession of architect, and some houses still existed in Darmstadt, the plans of which he had drawn when a youth at the Gymnasium. At Giessen, where he went to study architecture, he attended Liebig's lectures, whereby he was enticed to chemistry. But his relations would not at first hear of his changing his profession, and he was given half a year's grace to think over it. He spent this time at the Polytechnicum at Darm- 